\title{
Current Management of Radioiodine Sialadenitis
}

\author{
Henry T. Hoffman • Umar S. Chaudhry • \\ Yusuf Menda $\cdot$ Robert A. Robinson
}

Published online: 15 March 2014

(c) Springer Science+Business Media New York 2014

\begin{abstract}
This review of radioiodine sialadenitis covers molecular mechanisms, demographics, and analysis of quality of life. Animal and human research addressing salivary gland damage from $\mathrm{I}^{131}$ therapy is reported, and supplemented with relevant studies addressing the effect of external beam therapy. An illustrative case example identifies abnormalities in the histopathology associated with radioiodine sialadenitis. Approaches to preventing and treating radioiodine sialadenitis are discussed.
\end{abstract}

Keywords Radioiodine sialadenitis $\cdot \mathrm{I}^{131} \cdot$ Sialadenitis . Sialendoscopy $\cdot$ Salivary swelling $\cdot$ Xerostomia $\cdot$ Thyroid cancer

\section{Background}

Seaweed extract was first described for treatment of thyroid gland enlargement (goiter) over 2,000 years ago. The medically active component of seaweed was accidently isolated in 1811 in the course of cleaning of seaweed-containing vats with sulfuric acid. This process produced colored crystals

H. T. Hoffman ( $\square)$

Department of Otolaryngology, University of Iowa, Iowa, IA, USA

e-mail: henry-hoffman@uiowa.edu

U. S. Chaudhry · Y. Menda

Department of Radiology, University of Iowa, Iowa, IA, USA

Y. Menda

Department of Radiation Oncology, University of Iowa, Iowa, IA, USA

R. A. Robinson

Department of Pathology, University of Iowa, Iowa, IA, USA which were shown, two years later, to be the element "iodine" from the Greek ioeides, "violet-colored" [1•].

After Fermi's isolation of radioactive isotopes of iodine in 1934, collaboration between scientists at the University of California, Berkeley, and physicians at Boston's Massachusetts General Hospital led to study of $\mathrm{I}^{131}$ in animals and then in humans $[2,3]$. These experiments were followed by a report of therapeutic use of radioiodine to successfully treat hyperthyroid patients in Boston and Berkeley in 1941 [4]. There are 37 known iodine isotopes ranging from ${ }^{108} \mathrm{I}$ to ${ }^{144} \mathrm{I}$ and all are radioactive except ${ }^{127} \mathrm{I}$. Although other beta-emitting isotopes have been used for therapeutic use, the remainder of this discussion of radioiodine focuses on the effects of $\mathrm{I}^{131}$.

In contemporary therapy, radioiodine is used at low doses to treat such benign hyperthyroid disorders as Grave's disease and hyperfunctioning nodules. Diagnostic use of $\mathrm{I}^{131}$ - largely replaced by $99 \mathrm{mTc}$-pertechnetate or ${ }^{123}$ I-also uses a very low dose [5•]. Radioiodine-induced salivary inflammation (sialadenitis) is dose-dependent. Because of the smaller negative effect on salivary function after exposure to low doses, the following discussion centers on use of radioiodine at higher doses for treatment of thyroid cancer.

High dose $\mathrm{I}^{131}$ is widely accepted as a useful adjunctive treatment for most patients with aggressive "functional" well-differentiated thyroid cancer (WDTC). The term "functional" refers to the capacity of the thyroid cancer to concentrate iodine. Debate continues not only regarding the indications for, but also the dose of, $\mathrm{I}^{131}$ recommended for most patients with WDTC. Desirable objectives prompting $\mathrm{I}^{131}$ administration are:

1. treatment of residual thyroid cancer-both at the primary site and metastases; and 
2. ablation of residual normal thyroid remnants:

(a) to achieve undetectable serum thyroglobulin ( $\mathrm{Tg}$ ) levels, to enhance post-treatment assessment of $\mathrm{Tg}$ levels to monitor for recurrence; and

(b) to increase the sensitivity of post-treatment radioiodine total-body scanning to monitor for recurrence and to assess the avidity of a tumor for radioiodine to direct further $\mathrm{I}^{131}$ therapy.

Although successful use of radioiodine to achieve these objectives would, logically, result in improved survival for all patients aggressively treated, an overall survival benefit has not been seen when $\mathrm{I}^{131}$ has been used for low-risk thyroid cancer [6-9]. Regional variance in the use of radioiodine for WDTC was reported in a contemporary study by Haymart et al. [10]. These investigators concluded that the lack of randomized controlled trials coupled with conflicting observational studies have led to broadly stated clinical guidelines leaving decisions regarding use of radioiodine to provider discretion. As a result, use of $\mathrm{I}^{131}$ treatment for WDTC varies widely between and even within many institutions.

Reported differences between juvenile and adult WDTC led Jarzab et al. [11] to recommend a "routine intensive approach" to treatment of children with $\mathrm{I}^{131}$, because of their "more advanced disease at diagnosis, increased propensity for recurrence, and greater radioiodine responsiveness". These investigators indicated that their treatment philosophy is derived from "published evidence of significant survival benefits, especially regarding recurrence-free survival". These same investigators reported that "radioiodine is generally safe" and list the side effects as "self-limiting, or easily prevented or treated" [11]. They reported that most patients are asymptomatic after treatment, but can develop mild myelosuppression ( $\sim 25 \%$ ), nasolacrimal obstruction ( $\sim 3 \%)$, and sialadenitis $(<5 \%)$. These authors dismiss the problems of post- $\mathrm{I}^{131}$ sialadenitis as "avoidable by administration of large amounts of sour liquids during therapy, increasing salivary $\mathrm{I}^{131}$ clearance".

In contrast, recognition of the deleterious effects of radioiodine and difficulties in treating those effects has led many others to adopt more restrictive use of $\mathrm{I}^{131}$. The value of administering radioiodine to ablate residual thyroid tissue to improve follow-up study has been questioned. Recent guidelines (2009) from the American Thyroid Association (ATA) state that whole-body scanning is no longer recommended one year after treatment for low-risk patients [12]. This report from the ATA also states that "clinical judgment must prevail in the decision-making process" regarding use of radioiodine for WDTC because of "the absence of data". Carballo and Quiros [13] suggest that, for low-risk patients, a combination of neck ultrasound and rhTSH-stimulated serum $\mathrm{Tg}$ is sufficient for detection of persistent or recurrent disease.
The negative effects of treatment with radioiodine include an increased risk of developing secondary cancers. These cancers tend to occur in organ systems with the greatest $\mathrm{I}^{131}$ exposure [5•]. Rubino et al. [14], by study of 6,841 European patients, identified a linear dose-response correlation of $\mathrm{I}^{131}$ treatment with increased risk of developing leukemia, salivary gland cancer, colorectal cancer, and bone and soft tissue cancer.

The remainder of this review addresses the negative effect of radioiodine on the salivary glands, with emphasis on strategies used to prevent radioiodine-induced sialadenitis. Further focus reports innovations addressing painful salivary gland swelling and xerostomia associated with stomatitis, oral candidiasis, dysphagia, taste disturbance, and dental caries [15•, 16, 17].

Convention in the United States has been to report the amount of $\mathrm{I}^{131}$ radioactivity delivered in the units millicuries $(\mathrm{mCi})$, in honor of Marie and her husband Pierre Curie. The International System of Units, the world's most widely used system of measurement, uses the alternative term "Becquerel" to describe a unit of radioactivity. Henry Becquerel (1852-1908) discovered spontaneous radioactivity ("Becquerel's rays") in 1896 and later shared the Nobel Prize for physics with his two doctoral students Marie Sklodowska-Curie and Pierre Curie in 1903. Recent efforts to alter convention in the United States to establish consistency with European convention warrant familiarity with the measurement term Becquerel $(\mathrm{Bq})$. The unit $\mathrm{Bq}$ is more commonly expressed as megabecquerels ( $\mathrm{MBq})$ and gigabecquerels $(\mathrm{GBq})$. One $\mathrm{mCi}$ is equivalent to $37 \mathrm{MBq}$ [18]. One $\mathrm{GBq}$ is equivalent to $27 \mathrm{mCi}$. Conversion tables are available on-line to simplify interpretation (search for "Radioactivity Units of Conversion").

\section{Magnitude of Problem}

Salivary gland injury after radioiodine treatment depends not only on the $\mathrm{I}^{131}$ dose administered but also on the method used to assess salivary damage. Broad summaries estimate that one out of three patients will have chronic salivary problems after $\mathrm{I}^{131}$ treatment with symptoms which include salivary swelling, salivary pain, and xerostomia [19, 20••]. Other authors have reported association of radioiodine therapy with acute sialadenitis (24-77\% of those treated) and chronic sialadenitis (11-61.1\%) [21•, 22-26].

Approximately 37,340 Americans were diagnosed with thyroid cancer in 2008; of those, $62-75 \%$ received radioiodine treatment [27, 28]. Precise determination of the magnitude of the morbidity associated with $\mathrm{I}^{131}$ administration is difficult, because of variability of the patient perception threshold for reporting salivary problems.

Xerostomia is a common complaint that results from use of medications with drying effects, the aging process, and 
hormonal changes (menopause), and as a result of less common autoimmune phenomena and treatment of the head and neck by external beam irradiation. These confounding variables may obscure the overall effect of $\mathrm{I}^{131}$ as a cause of xerostomia. It is reported that the sensation of oral dryness does not usually occur until the normal unstimulated flow rate is reduced by approximately $50 \%$ $[29,30]$. Submandibular gland hypofunction is believed to be a more important cause of the symptoms of xerostomia than parotid hypofunction. Under resting conditions, approximately two thirds of saliva is produced by the submandibular gland [31-33].

Xerostomia was the focus of study by Jeong et al. [20••], who reported dry mouth was a complication for $16.4 \%$ of patients after a single dose $(100-150 \mathrm{mCi})$ of radioiodine. This complaint was dose dependent, occurring among $17.9 \%$ of patients after $(150 \mathrm{mCi}) 5.55 \mathrm{GBq}$ and among $7.8 \%$ of patients after $3.7 \mathrm{GBq}(100 \mathrm{mCi})$. Jeong et al. limited their study to patients without other causes of xerostomia. They reported a remarkable long-term comparative analysis of pre-treatment (1-2 weeks before radioiodine ablation) with post-treatment (60 months after radioiodine), with assessment by use of salivary gland scintigraphy with $10 \mathrm{mCi}$ of $99 \mathrm{mTc}-$ pertechnetate. Each of the four separate submandibular and parotid glands were evaluated independently, leading to analysis of 852 salivary glands (213 patients). Abnormal (diminished) uptake of $99 \mathrm{mTc}$ pertechnetate after radioiodine therapy was observed for $21.3 \%$ of glands $(30.3 \%$ of parotids abnormal; $9.4 \%$ of submandibular glands abnormal). Diminished function of at least once gland after radioiodine treatment was observed for 101 of the 213 patients (47.4\%). For most of those with diminished function, the damage was limited to either one gland $(38.6 \%)$ or two glands $(49.5 \%)$. The patients' subjective reports of dry mouth correlated with results from objective measurement of submandibular dysfunction rather than parotid dysfunction. Jeong et al. concluded that $\mathrm{I}^{131}$ treatment should be limited to the minimum dose of radioiodine adequate for thyroid remnant ablation. They also call for more work to investigate the "Cincinnati" regimen (Table 1) used to diminish radiation sialadenitis, in an effort to repeat the more favorable results with this treatment as reported by Silberstein [21•].

Pain and swelling of the salivary glands rather than xerostomia have been the focus of other study evaluating complications from radioiodine. Ann et al. [19] prospectively studied 118 patients with WDTC, treated by surgery then a single dose of $\mathrm{I}^{131}$, over a 13 month period ending in August 2011. Subjective symptoms of salivary pain and swelling were initially evaluated seven days before treatment, a second time within seven days of administration, and then finally between 100 and 596 days after treatment.
Pain and swelling were reported by $34 \%$ (40/118) of patients during the acute period. Acute or chronic symptoms developed in a dose-dependent fashion with overall occurrence in $11 \%$ ( 2 of 19 patients) who received $30 \mathrm{mCi}$ and in $50 \%$ (50 of 99 patients) who received $100 \mathrm{mCi}$ or higher.

\section{Quality of Life (QOL)}

The negative effect of radiation-induced sialadenitis on QOL has been intensively studied. Most reports have focused on use of external beam irradiation to treat squamous cell carcinoma of the head and neck [34]. Although the outcome is dose and site-dependent, it is estimated that approximately half of those treated with external beam irradiation of the head and neck will experience irreversible damage to irradiated salivary glands [35]. The resulting dramatic reduction in saliva is associated with discomfort, mucositis, oral infections, and marked decline in QOL [36, 37].

More specific analysis of the effect of radioiodine treatment on QOL was first reported by Almeida et al. [38], who used the University of Washington QOL questionnaire to conduct a cross-sectional analysis . Analysis included 154 patients with stages I or II WDTC treated with total thyroidectomy (100\%), paratracheal neck dissection (17.5\%), radical neck dissection $(7.1 \%)$, and radioiodine $(60.4 \%)$. The median dose of radioiodine was $130 \mathrm{mCi}$ (range $30-700 \mathrm{mCi}$ ). These investigators found post-treatment scores for recreation, activity, speech, saliva, and composite assessment were significantly depressed. Patients who received more than $150 \mathrm{mCi}$ reported significantly worse pain, swallowing, chewing, speech, taste, and anxiety resulting in a decrease in their aggregate "composite score". Patients treated with radical neck dissection had significantly worse chewing and shoulder problems. Multivariate analysis that included extent of surgical treatment as a variable revealed that dose of radioiodine greater than $150 \mathrm{mCi}$ was the only variable associated with a worse composite score.

Dysphagia may result from laryngeal paralysis occurring as a result of either thyroid cancer or the surgery performed to treat the cancer [39]. Dysphagia also occurs among patients who receive radioiodine post-thyroidectomy in the absence of laryngeal paralysis and has been attributed to radioiodine-induced xerostomia with attendant difficulties in draining saliva [16].

\section{Radiographic Evaluation}

Pain and swelling of the salivary glands after radioiodine treatment may also result from processes unrelated to the $\mathrm{I}^{131}$ treatment and in selected cases may warrant a more general approach to salivary swelling (Hoffman HT (ed) Iowa Head and Neck Protocols "Salivary Swelling" 
Table 1 Selected methods for prevention of sialadenitis after irradiation

\begin{tabular}{|c|c|c|c|}
\hline Prevention strategies & Studies & Study characteristics & Conclusions \\
\hline \multicolumn{4}{|l|}{ Radioiodine irradiation } \\
\hline Reduction of dose of $\mathrm{I}^{131}$ administered & $\begin{array}{l}\text { Multiple } \\
\text { studies } \\
\text { including } \\
\text { Refs. [58, } \\
\text { 59] }\end{array}$ & $\begin{array}{l}\text { Human (clinical) study-analyzing } \\
\text { effectiveness of thyroid ablation with low- } \\
\text { dose radioiodine measured by post- } \\
\text { treatment rhTSH-stimulated thyroglobulin } \\
\text { assessment and post-treatment } \mathrm{I}^{131} \\
\text { scintigraphy }\end{array}$ & $\begin{array}{l}\text { For appropriately selected cases post- } \\
\text { surgical residual thyroid tissue may be } \\
\text { successfully ablated with } 30 \mathrm{mCi} \\
(1.1 \mathrm{GBq}) \mathrm{I}^{131} \text {; emphasis is placed on } \\
\text { complete surgical excision-to limit the } \\
\text { dose required for ablation and in some } \\
\text { cases avoid the need for radioiodine } \\
\text { ablation }\end{array}$ \\
\hline $\begin{array}{l}\text { Administration of sialogogues (lemon } \\
\text { candy) at time of } \mathrm{I}^{131} \text { treatment }\end{array}$ & $\begin{array}{l}\text { Nakada et al. } \\
{\left[62^{\bullet}\right]}\end{array}$ & $\begin{array}{l}\text { Human (clinical) study-sucking lemon } \\
\text { candy }<1 \text { h (group A) or }>24 \text { h (group B) } \\
\text { after } \mathrm{I}^{131} \text { ingestion }\end{array}$ & $\begin{array}{l}\text { Xerostomia, altered taste, and sialadenitis } \\
\text { highest among those treated with candy at } \\
\text { the time of treatment (group A) }\end{array}$ \\
\hline $\begin{array}{l}\text { Parasympathetic stimulation } \\
\text { immediately after } 131 \\
\text { administration }\end{array}$ & $\begin{array}{l}\text { Silberstein } \\
{\left[21^{\bullet}\right]}\end{array}$ & $\begin{array}{l}\text { Human (clinical) study-randomized } \\
\text { controlled study of } 60 \text { patients receiving } \\
\text { either placebo or pilocarpine } 5 \mathrm{mg} \text { orally } \\
\text { every } 8 \mathrm{~h} \text { for } 1 \text { week after } \mathrm{I}^{131} \text { therapy }\end{array}$ & $\begin{array}{l}\text { No benefit seen in pilocarpine group } \\
\text { compared with control-reason for lack of } \\
\text { benefit ascribed to success of "Cincinnati } \\
\text { regimen" used for both the study and } \\
\text { control groups with equally good results } \\
\text { (no acute sialadenitis) }\end{array}$ \\
\hline $\begin{array}{l}\text { "Cincinnati regimen" intense } \\
\text { sialorrheic management with hydration } \\
\text { during and after } \mathrm{I}^{131} \text { treatment }\end{array}$ & $\begin{array}{l}\text { Silberstein } \\
{[21 \bullet]}\end{array}$ & $\begin{array}{l}\text { Oral } 8 \mathrm{mg} \text { of dexamethasone and } 100 \mathrm{mg} \text { of } \\
\text { dolasetron } 2 \mathrm{~h} \text { before therapy and every } \\
12 \mathrm{~h} \text { for five doses after } \mathrm{I}^{131} \text { ingestion } \\
2,400 \mathrm{~mL} \text { nondairy liquid per day for the } \\
\text { week after therapy } \\
\text { Sugar-free gum or candy in the mouth at all } \\
\text { times when awake for a week and for the } \\
\text { first three nights, awaken every } 3 \mathrm{~h} \text { to } \\
\text { reapply sialogogues and then brush mouth } \\
\text { with soft toothbrush and water for } 1 \text { min }\end{array}$ & $\begin{array}{l}\text { Remarkably low incidence of salivary } \\
\text { problems supports further investigation of } \\
\text { this approach. Relative importance of } \\
\text { contributions of dexamethasone (anti- } \\
\text { inflammatory) and dolasetron } \\
\text { (secretogogue), given primarily because of } \\
\text { their anti-emetic properties, is unclear }\end{array}$ \\
\hline $\begin{array}{l}\text { Amifostine (free radical scavenger) } \\
\text { administered intravenously before } \mathrm{I}^{131} \\
\text { treatment }\end{array}$ & $\begin{array}{l}\text { Ma et al. } \\
{\left[68^{\bullet}\right]}\end{array}$ & $\begin{array}{l}\text { Human (clinical) studies-review of } \\
\text { literature focused on two randomized } \\
\text { controlled studies, a German study by } \\
\text { Bohuslavizki et al. [69] and a Korean } \\
\text { study by Kim et al. [70] }\end{array}$ & $\begin{array}{l}\text { Review of randomized controlled studies } \\
\text { concluded there was no radioprotective } \\
\text { effect of amifostine on the salivary glands } \\
\text { despite inclusion of the early study } \\
\text { (Bohuslvizki et al. [69]) suggesting there } \\
\text { was benefit }\end{array}$ \\
\hline \multicolumn{4}{|l|}{ External beam irradiation } \\
\hline $\begin{array}{l}\text { Before irradiation inject the glands } \\
\text { with botulinum toxin (chemical } \\
\text { denervation) to induce temporary } \\
\text { involution }\end{array}$ & $\begin{array}{l}\text { Teymoortash } \\
\text { et al. [87] }\end{array}$ & $\begin{array}{l}\text { Animal (rat) study-botulinum toxin } \\
\text { injected to one of the two submandibular } \\
\text { glands } 14 \text { days before external beam } \\
\text { irradiation ( } 20 \text { Gy single dose) }\end{array}$ & $\begin{array}{l}\text { Protective effect of botulinum toxin } \\
\text { documented by salivary } \\
\text { lymphoscintigraphy and histologic } \\
\text { analysis ( } 95 \text { days after treatment) }\end{array}$ \\
\hline $\begin{array}{l}\text { Before irradiation infuse glands with } \\
\text { a protein (TLK1B) that facilitates DNA } \\
\text { repair and cell survival }\end{array}$ & $\begin{array}{l}\text { Sunavala- } \\
\text { Dossabhoy } \\
\text { et al. [88] }\end{array}$ & $\begin{array}{l}\text { Animal (rat) study-deleterious effects of } \\
\text { external beam irradiation (16 Gy) } \\
\text { attenuated by infusion of submandibular } \\
\text { salivary ducts with modified TLK1B } \\
\text { protein before XRT }\end{array}$ & $\begin{array}{l}\text { Potential for infusion of protective/ } \\
\text { reparative protein "safer alternative to } \\
\text { gene therapy" }\end{array}$ \\
\hline $\begin{array}{l}\text { During irradiation administer } \\
\text { acupuncture three times a week }\end{array}$ & $\begin{array}{l}\text { Meng et al. } \\
\text { [72] }\end{array}$ & $\begin{array}{l}\text { Human (clinical) study randomizing patients } \\
\text { under treatment for nasopharyngeal } \\
\text { carcinoma with external beam irradiation }\end{array}$ & $\begin{array}{l}\text { Significantly greater salivary flow and } \\
\text { diminished symptoms of xerostomia in } \\
\text { treated group possibly related to the } \\
\text { acupuncture stimulating the brain or } \\
\text { producing neuropeptides }\end{array}$ \\
\hline $\begin{array}{l}\text { Gene therapy (cDNA for hKGF in } \\
\text { adenovirus vector) instilled into } \\
\text { submandibular glands before } \\
\text { irradiation exploiting function of KGF } \\
\text { (keratinocyte growth factor) to } \\
\text { regenerate damaged epithelium }\end{array}$ & $\begin{array}{l}\text { Zheng et al. } \\
\text { [73] }\end{array}$ & $\begin{array}{l}\text { Animal (mouse) study-infuse glands of } \\
\text { eight-week-old mice by cannulation and } \\
\text { retrograde delivery of cDNA viral vector } \\
\text { versus control then irradiated (single dose } \\
15 \mathrm{~Gy} \text { and second group with } 6 \mathrm{~Gy} \text { daily } \\
\text { fractions for } 5 \text { days) with endpoints } \\
\text { including stimulated (pilocarpine) salivary } \\
\text { flow analysis }\end{array}$ & $\begin{array}{l}\text { Transfer of the hKGF gene to SGs before } \\
\text { both fractionated and single-dose IR } \\
\text { substantially prevents salivary } \\
\text { hypofunction. Not yet clear whether } \\
\text { salivary parenchymal, endothelial, and/or } \\
\text { progenitor cells/stem cells are all targets } \\
\text { of the transgenic hKGF }\end{array}$ \\
\hline
\end{tabular}




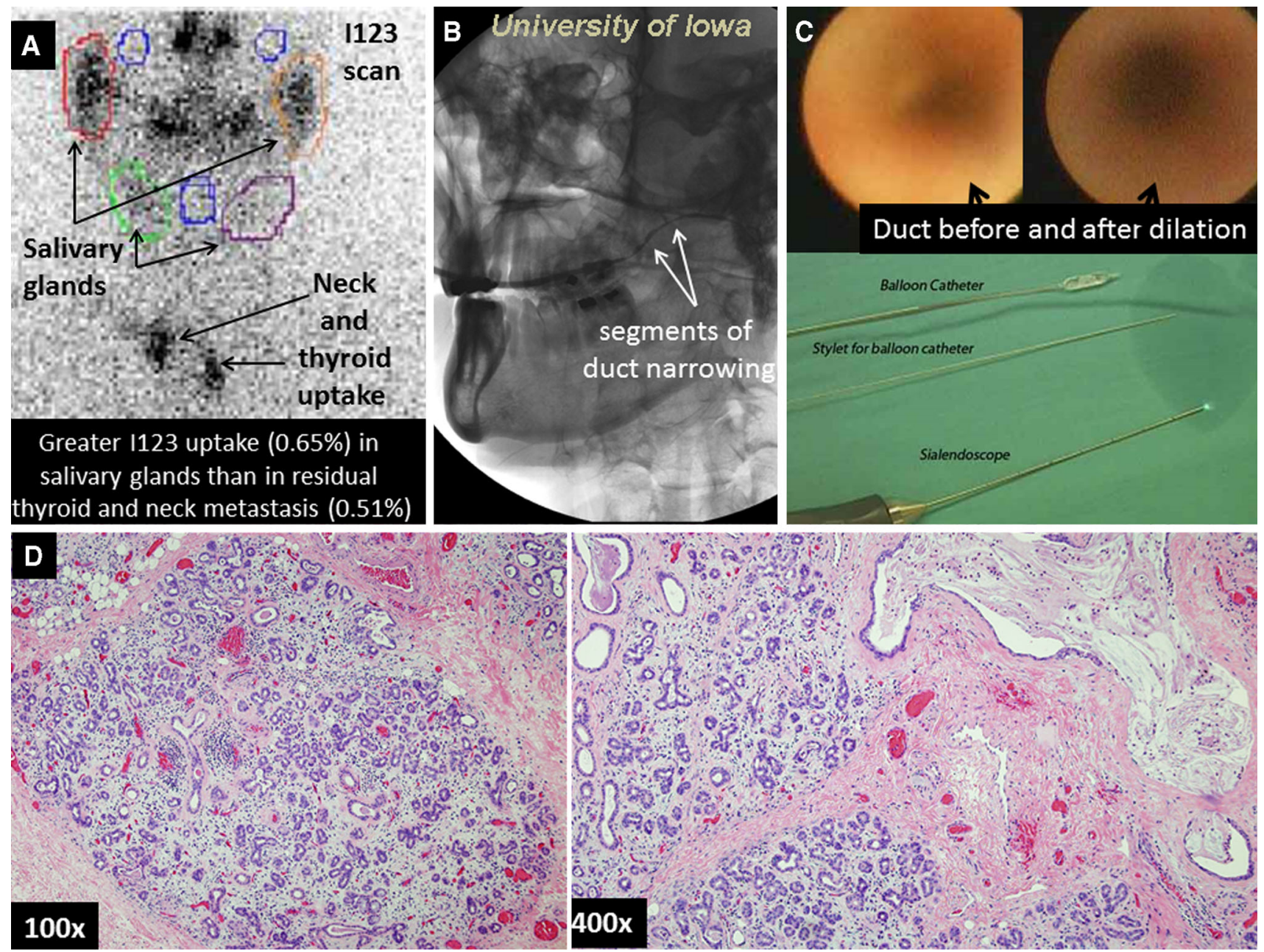

Fig. 1 a I123 scan performed one month after total thyroidectomy with salivary uptake $(0.65 \%)$ greater than thyroid remnant and neck metastasis uptake $(0.51 \%)$. Note greater uptake in the parotid glands than the submandibular glands. b Left parotid sialogram performed eight months after administration of $187.7 \mathrm{mCi}$ of $\mathrm{I}^{131}$ reveals several areas of short-segment narrowing and dilation of the main parotid duct. c Bilateral parotid sialendoscopy was performed; duct narrowing and debris were revealed. Successful balloon dilation is revealed by pre and post-dilation imaging with sialendoscopy. d. Histopathology of the

https://wiki.uiowa.edu/display/protocols/Salivary+Swelling accessed 29 December 2013). Variations between institutions and patients suggest a personalized approach to diagnostic imaging. Although general recommendations are available for direct radiographic imaging of salivary swelling, reports specific to imaging of glands suspected of having radioiodine injury are less common [40-43]. Salivary imaging modalities range from the now rarely used plain radiographs to more commonly used sialograms, CT, MRI, ultrasound, and dynamic MRI scans [44].

Initial evaluation of acute sialadenitis after RAI therapy is often appropriately limited to a history and physical examination. Radiographic imaging in this scenario is usually resected submandibular gland revealed mild lobular inflammation with depletion of acini and acinar atrophy (left image $\times 100$ ). Ductal dilatation, with accompanying attenuation of ductal mucosa and early squamous metaplasia of the ducts, is present. Ductal concretions are apparent, as is early periductal fibrosis (right image $\times 400$ ) (with permission from Iowa Protocols: web page: Hoffman HT (ed) Iowa Head and Neck Protocols "I ${ }^{131}$ Sialadenitis (Radioiodine Sialadenitis)" https://wiki.uiowa.edu/pages/viewpageattachments.action?pageId=52 134351 accessed 14 January 2014)

reserved for unusual signs or symptoms of more advanced disease-for example that indicating possible abscess formation. In most cases no additional investigation is needed other than to refer to the standard post- ${ }^{131}$ treatment scan usually performed one week after therapy. Evaluation of this specific image is often useful to demonstrate predominant uptake by the symptomatic gland(s) [45]. Uptake by the serous-dominant parotid glands is more commonly reported than uptake by the submandibular glands. Further analysis of the radioiodine scan enables measurement reported as percentage radioiodine uptake (Fig. 1).

Use of radiographic imaging of the salivary glands to assess the long-term effects of radioiodine is more 
established. Scintigraphy is used most commonly for research purposes to assess salivary gland function; $99 \mathrm{mTc}$ is the current agent of choice [20•]. CT Imaging may be useful for revealing indirect evidence of chronic salivary dysfunction, as reported by Nabaa et al. [46]. These authors showed that volume loss and increased attenuation are markers of dysfunction. An increase of $10 \mathrm{HU}$ (Hounsfield units) correlates with severe gland dysfunction. This attenuation is identified several months to a year after radioiodine treatment and has been ascribed to fibrosis.

Ultrasound may characterize chronic sialadenitis with affected glands shown to be small in size, hypoechoic, inhomogeneous, and with reduced blood supply [43]. CT sialography has been reported to be a useful, more refined technique, with improved spatial resolution, for imaging of ductal abnormalities [47].

Although conventional sialography with fluoroscopy has been supplanted in many institutions by other imaging techniques, we find it useful for imaging of ductal abnormalities that cannot be accessed by sialendoscopy or seen on static imaging (Fig. 1). The "fourth dimension" (time) is a component of conventional sialography that enables review not only of a static sequence of images but also video recording of insufflation and emptying of radiocontrast in the glands (Ref. Iowa Protocols: web page: Hoffman HT (ed) Iowa Head and Neck Protocols "Sialograms and Sialography" https://wiki.uiowa.edu/display/protocols/ Sialograms+and+Sialography accessed 15 December 2013).

\section{Case Example}

An illustrative case is presented of a patient treated for an aggressive papillary thyroid cancer (extrathyroidal extension of 6-cm tumor with capillary lymphatic invasion) by total thyroidectomy then, one month later, diagnostic I123 study (Fig. 1a) (Ref. Iowa Protocols: web page: Hoffman HT (ed) Iowa Head and Neck Protocols "I ${ }^{131}$ Sialadenitis (Radioiodine Sialadenitis)" https://wiki.uiowa.edu/pages/ viewpageattachments.action?page $\mathrm{Id}=52134351$ accessed 14 January 2014). Two days later $187.7 \mathrm{mCi} \mathrm{I}^{131}$ was administered with amifostine and standard use of hydration and sialogogues. Despite these measures the patient developed immediate swelling of both parotid glands for two days with resolution until recurrent parotid swelling occurred five months later with onset of xerostomia.

Eight months after radioiodine treatment a sialogram of the more affected left parotid revealed multiple areas of short segment narrowing and dilation of the main parotid duct suggestive of postradiation change (Fig. 1b). Two days later bilateral parotid sialendoscopy revealed duct narrowing and debris. The ducts were irrigated, dilated (balloon), and then infused with $3 \mathrm{~cm}^{3}$ triamcinolone
(Kenalog 10) (Fig. 1c). There was no further parotid swelling or pain with three year follow-up.

Xerostomia continued with onset of submandibular swelling and pain occurring with meals that developed one year after receiving the $\mathrm{I}^{131}$. Difficulty was experienced cannulating the left submandibular gland, but successful cannulation of the right submandibular gland enabled delivery of triamcinolone (Kenalog 10) under local anesthesia. Relief of the painful swelling of the right submandibular gland was accompanied by continued pain and swelling of the left submandibular gland. Resection of the submandibular gland 19 months after treatment with $\mathrm{I}^{131}$ resulted in final resolution of the salivary pain and swelling but persistence of xerostomia.

Histopathology of the resected submandibular gland revealed attenuation of ductal mucosa with early squamous metaplasia and early periductal fibrosis (Fig. 1d). Acinar lobular inflammation with depletion of acini, acinar atrophy, and ductal concretions were also identified.

\section{Molecular Mechanisms}

Pain and swelling of the salivary glands after radioiodine treatment are associated with an inflammatory process that affects the acini in association with duct constriction and increased periductal pressure [15•]. The ductal cells of the salivary glands concentrate iodine in a tissue-to-serum ratio of 50:1 [48]. A plasma membrane glycoprotein termed the sodium-iodide symporter (NIS) is responsible for concentrating the iodine intracellularly. This concentration of iodine also occurs in organs containing the NIS including thyroid follicular cells, lacrimal glands, and gastric mucosa. It has been estimated that up to $24 \%$ of the administered dose of radioactive iodine passes through saliva [49].

An animal study has shown that iodine is concentrated in ductal cells, but not in acinar cells [50]. The location of the NIS in the ductal system has implications for therapeutic intervention targeting the ductal system for treatment with special focus on strictures induced by radioiodine [51•]. Despite this reported localized effect on the ductal system, the acinar cells are also affected by $\mathrm{I}^{131}$ in a manner that is not clearly defined. The greater effect of $\mathrm{I}^{131}$ on the parotid gland has been ascribed to greater radiosensitivity of the serous cells predominant in the parotid acini compared with the predominant mucus secreting cells in the submandibular acinar units [52].

Jentzen et al. [50] analyzed salivary radioiodine uptake and distribution and proposed an alternative hypothesis for the different radiosensitivity of the parotid and submandibular glands. These investigators suggest that the greater continuous unstimulated secretion of the submandibular gland clears the toxic iodine. As a result, the 
submandibular gland is exposed for a shorter period of time than the parotid gland, which would be expected to retain iodine on the basis of its intermittent secretion that occurs only with stimulation. Jentzen et al. discovered that the extent of salivary gland damage resulting from $\mathrm{I}^{131}$ treatment is greater than would be predicted in applying the well-known dose-effect relationship established for external beam irradiation. They concluded that inhomogeneous distribution of $\mathrm{I}^{131}$ activity in the salivary glands may cause isolated regions of greater damage which explain the extent of injury seen.

Others have postulated that radioiodine injury to both the acini and ductal cells results secondarily from damage to the vasculature of the glands [53]. This radiation damage to the dividing endothelial cells is postulated to induce injury by interfering with blood supply.

Another perspective regarding molecular mechanisms of the effect of radiation comes from an animal study of the effect of external beam irradiation on the salivary glands. In 1983 Abok et al. [54] discovered that the quantity of secretary granules in the salivary acini correlated with the extent of gland damage after external beam irradiation. Nagler [55] theorized that the high concentration of heavy metals (including iron and copper) in these secretory granules may increase sensitivity to ionizing radiation leading to cell death.

Tissue classically believed to be radiosensitive is usually characterized by rapidly dividing cells. The highly differentiated and "almost non-cycling" functional salivary cells (acinar cells) should, theoretically, be resistant to radiation, as observed in a review of salivary radiosensitivity by Konings et al. [56]. Konings et al. concluded there were two separate mechanisms for salivary dysfunction occurring in the early and late phases, respectively, after irradiation. The early defects in cellular function result from membrane damage. Late-phase effects are because of radiation killing of progenitor cells and damage to the cellular environment. These investigators reported a classification scheme for radiation damage to the salivary glands as occurring in four phases based on study of localized external beam irradiation of rat salivary glands with 15 Gy [57].

- Phase I (0-10 days: acute phase) impaired water secretion, reduced to $60 \%$ of that of the non-irradiated state, with no cell loss observed. Hypothesis that damage to the plasma membrane interferes with interactions with cell membrane receptors (M3 muscarinic) and/or Gq-proteins.

- Phase II (10-60 days) acinar cells disappear, presumably because of plasma membrane damage with decrease in secretion of amylase.

- Phase III (60-120 days) no major changes in cell number or salivary flow.
- Phase IV (120-240 days late radiation phase) marked lack of functional acinar cells caused by killing of progenitor and stem cells-some reformation of acinar cells that do not function properly because of damage to ducts, blood vessels, and nerves.

These studies of the effects of external beam irradiation on the salivary glands offer insight into preventative and therapeutic strategies that can be used to manage radioiodine-induced sialadenitis.

\section{Prevention of Radioiodine Salivary Damage}

$\mathrm{I}^{131}$ Dose Reduction

Recent large studies have shown successful ablation of postsurgical residual thyroid tissue by use of a lower dose of $30 \mathrm{mCi}(1.1 \mathrm{GBq}) \mathrm{I}^{131}[7,58]$. The results show it is possible to effectively treat selected thyroid cancer with lower doses of radioiodine and reduce salivary gland toxicity. Comprehensive surgery (complete total thyroidectomy with negligible uptake on diagnostic post-surgery scan) is proposed as an additional strategy to avoid the need for radioiodine treatment of low-risk thyroid cancer [59]. In addition, selected low-risk thyroid cancer may be effectively treated without the need for either total thyroidectomy or $\mathrm{I}^{131}$ therapy [60]. The trend in the US has been toward limiting use of radioiodine for low-risk disease [61].

\section{Sialogogues}

Nakada et al. [62•] investigated what they then believed to be standard use of sialogogues in an effort to reduce the side effects of $\mathrm{I}^{131}$ therapy. Although massage of the glands was not mentioned as intervention in their study, the universally accepted emphasis on hydration during the period of treatment was addressed by supplementing oral fluids with IV fluids when necessary during the four days after $\mathrm{I}^{131}$ administration. It is noteworthy that in the US posttherapy hydration is encouraged through oral intake rather than intravenous hydration, because most $\mathrm{I}^{131}$ therapy is performed on outpatients.

In their study, Nakada et al. evaluated a consecutive series of patients treated with $\mathrm{I}^{131}$ for WDTC. They compared 116 patients who received lemon candy within $0.5 \mathrm{~h}$ of ingesting $\mathrm{I}^{131}$ (group A from August 1999 to October 2000) with 139 patients who received the candy more than $24 \mathrm{~h}$ after treatment (group B from November 2000 to June 2002) [62•]. There were no differences between the two groups in respect of mean age and mean dose of $\mathrm{I}^{131}$ (3.96 vs. $3.87 \mathrm{GBq}$ ). Exclusion of patients with preexisting 
salivary gland disorders, diabetes, collagen tissue tissues, and a previous history of neck irradiation yielded 105 patients in group A and 125 patients in group B. Incidence of xerostomia and sialadenitis, and altered taste, were significantly higher for patients receiving lemon candy immediately after $\mathrm{I}^{131}$ ingestion than for those delaying use of the sialogogue for $24 \mathrm{~h}$. These investigators postulated that increased salivary blood flow in the group receiving lemon candy at the time of $\mathrm{I}^{131}$ administration induced greater uptake of the damaging radioiodine.

Controversy persists regarding the potential negative effect of early application of sialogogues in an effort to reduce salivary damage from $\mathrm{I}^{131}$ therapy [63]. Van Nostrand et al. [64] disagreed with Nakada's conclusions on the basis of a study of the pharmacokinetics of radioiodine in the salivary glands in 23 patients administered lemon juice $2 \mathrm{~h}$ after administration of $15-37 \mathrm{MBq}(0.4-1 \mathrm{mCi})$ I123. Van Nostrand et al. reported a rapid decline in radioiodine in treated parotid glands within $4 \mathrm{~min}$ of administering lemon juice with rapid re-accumulation of radioiodine in the glands $20-40 \mathrm{~min}$ later. On the basis of their study they recommend that sialogogues (e.g. lemon juice) be administered $2 \mathrm{~h}$ after $\mathrm{I}^{131}$ administration and then every 15-30 min afterwards (potentially continually). They remarked that more information is needed to assess the pharmacokinetics in the first early period (first $2 \mathrm{~h}$ ) after I $^{131}$ administration.

\section{Parasympathetic Stimulation}

Alexander et al. [24] administered a questionnaire to 203 patients to address symptoms termed intermediate (within three months) and long-term (greater than a year) after total thyroidectomy then treatment with $\mathrm{I}^{131}(100-200 \mathrm{mCi})$. Intermediate side effects occurred in $76.8 \%$ of patients and long-term side effects were reported by $61.1 \%$ of patients. Reduced salivary function was reported for $42.9 \%$, despite use of pilocarpine by a subset of patients at the time of $\mathrm{I}^{131}$ treatment. The pilocarpine was administered in an attempt to increase discharge of iodine from the salivary glands to reduce the negative effects. These investigators reported a non-significant trend toward reduced side effects of $\mathrm{I}^{131}$ in the group receiving pilocarpine.

More recently, Silberstein [21•] from Cincinnati reported no benefit for 60 patients randomized to receive pilocarpine $5 \mathrm{mg}$ orally every $8 \mathrm{~h}$ for one week after $\mathrm{I}^{131}$ therapy. The lack of expected benefit was explained by this investigator as being because of excellent results in both study and control groups. Silberstein reported that the study and control groups received the same strong sialorrheic "Cincinnati regimen" that may have masked any small additional benefit of use of pilocarpine.
This report by Silberstein introduced the "Cincinnati regimen" (Table 1) as effective to the point that "acute sialadenitis (swollen, painful salivary glands) within a few days after therapy never occurred in either group". Silberstein did report that one patient in the pilocarpine group and two in the control group had mild salivary tenderness on palpation 4-10 days after therapy. The mean $\mathrm{I}^{131}$ activity administered was $4.40 \mathrm{GBq}$ in the group receiving pilocarpine and 4.92 in the control group. The lower than expected occurrence and lower severity of radiation sialadenitis was attributed to pre- $\mathrm{I}^{131}$ treatment with an intense regimen of dexamethasone, dolasetron, hydration, and sialogogues continued post-treatment. This intense regimen included family member involvement to ensure ingestion of at least $2,400 \mathrm{~mL}$ non-dairy liquid daily in the week after therapy, awakening every $3 \mathrm{~h}$ for the first three nights to urinate, chew gum, or suck candy and gently brush the oral mucosal surfaces with a soft toothbrush and water for a minute before expectorating. Gum or sugar-free candy was also used continually during waking hours. Dolasetron mesylate $(100 \mathrm{mg})$ and dexamethasone $(8 \mathrm{mg})$ were given $2 \mathrm{~h}$ before $\mathrm{I}^{131}$ therapy and every $12 \mathrm{~h}$ for another five doses after $I^{131}$ ingestion. In this study, administration of dolasetron and dexamethasone successfully reduced nausea and vomiting but may also have had an unintended benefit. Silberstein reports that dolasetron is a serotonin receptor blocker that functions also as a secretogogue and that dexamethasone functions as an anti-inflammatory.

\section{Amifostine}

Amifostine is an organic thiophosphate that, in normal tissue, is dephosphorylated by alkaline phosphatase to the agent WR-1065 which functions intracellularly as a scavenger of free radicals. It was initially developed as a radioprotective agent by the US Army in the 1950s, to protect against the effects of nuclear warfare [65]. Amifostine is believed to selectively protect non-malignant tissues from the effect of radiation because of its greater accumulation by normal tissue and the diminished activity of alkaline phosphatase activity in tumor tissue [66]. Amifostine has also been reported to accumulate to a higher level in salivary tissue and to negligible levels in thyroid tissue.

Promising results from early study included those reported from Germany by Bohuslavizki et al. [67], who reported preservation of salivary function and protection from xerostomia, for 25 amifostine-treated patients. More recent study has not supported continued use of amifostine to protect against $\mathrm{I}^{131}$-induced sialadenitis. Ma et al. [68•] reviewed the protective effect of amifostine on radioiodineassociated sialadenitis. They focused solely on prospective randomized controlled studies which included that by Bohuslavizki et al. [69] and a more recent study from Korea 
(Kim et al. [70]). The review by Ma et al. concluded that amifostine has no significant radioprotective effects on salivary glands exposed to radioactive iodine.

\section{Botulinum Toxin}

A rat study by Teymoortash et al. [87] revealed that injection of botulinum toxin into one submandibular gland (saline placebo into the other) 14 days before a single dose (20 Gy) of external beam irradiation significantly reduced radiation damage to the treated gland. These investigators proposed that transient pharmacologic denervation with botulinum toxin causes gland atrophy and reduced the amounts of secretory granules in the acinar cells. They postulate that protection from radiation damage occurred without any negative effect that may have resulted from increased blood supply to the glands. It has been theorized that increased blood supply to the gland might occur as a result of dilation of adjacent blood vessels as a result of the botulinum. Ansiaux et al. [71] have suggested that peritumoral infusion of botulinum toxin could inhibit neurogenic tone in the vasculature, leading to increased blood supply and attendant oxygenation which enhances the radiosensitivity of the cancer.

\section{Acupuncture}

Meng et al. [72] at the Fudan University in Shanghai China reported the results of a randomized trial evaluating acupuncture designed to prevent radiation-induced xerostomia among patients with nasopharyngeal carcinoma. Forty patients treated with acupuncture three times a week in the course of receiving radiation reported significantly better subjective ratings of salivary flow than the 46 who did not receive acupuncture. Objective analysis of stimulated and unstimulated salivary flow three weeks into treatment, at seven weeks and then six months post-treatment identified statistically better outcome for the group receiving acupuncture. Efforts were made to integrate traditional Chinese medicine theory and biomedicine with placement of needles at several body points; the needles were left in place for $20 \mathrm{~min}$. The authors propose that their favorable outcomes could result from several mechanisms including acupuncture-induced brain stimulation and secretion of neuropeptides, resulting in increased salivary flow.

\section{Gene Therapy}

Retrograde salivary ductal instillation to introduce genetic material has been studied for prevention of radiation damage to salivary glands. Zheng et al. [73] investigated use of retrograde insufflation of human keratinocyte growth factor (hKGF) gene (cDNA in a viral vector) to murine salivary glands before external beam irradiation. This treatment prevented salivary hypofunction, presumably because of the function of hKGF, which regenerates damaged epithelium.

\section{Treatment}

Oral Parasympathetic Medication

Oral cholinergic medications with muscarinic activity have been successfully used to stimulate salivary flow in patients with xerostomia after $\mathrm{I}^{131}$ treatment. Aframian et al. [74•] reported that oral administration of $5 \mathrm{mg}$ pilocarpine resulted in successful short-term salivary stimulation for four of five patients with post-I ${ }^{131}$ xerostomia (Table 2).

Pilocarpine has broader muscarinic activity than cevimeline which is more specific for the M3 muscarinic receptor located on lacrimal and salivary epithelium. As a result, cevimeline has been promoted as having fewer systemic side effects-most notably sweating. However, a clinical trial comparing the two drugs in a cross-over, double-blind study for management of xerostomia with a variety of causes showed increased salivary secretion for both and no perceived differences in side effects [75]. Excluded from this study were patients with uncontrolled chronic obstructive pulmonary disease, depression, asthma, cardiac arrhythmias, glaucoma, and use of medication with interactions with the oral cholinergics. The observed side effects from treatment with either cevimeline or pilocarpine included not only sweating, but also nausea, headache, watering from the eyes, stomach upset, diarrhea, and pain around the eyes. The authors conclude that these cholinergic medications may be appropriate treatment for patients with dry mouth, but the advantages and disadvantages must be considered, taking into account the undesirable side effects.

\section{Sialendoscopy}

Nahlieli and Nazarian [51•] reported results for the first series of patients treated by sialendoscopy for symptomatic radioiodine sialadenitis. They reported that the initial symptoms of pain and swelling after treatment resulted from inflammatory narrowing of the duct lumen with "salivary stagnation" and "mucus precipitation". They also identified chronic post-radiation changes associated with duct stricture. Their targeted approach used sialendoscopy for 15 patients to aid diagnosis and treatment. "Hydrostatic saline lavage pressure" was used for all patients and supplemented by use of a sialoballoon for one patient in an effort to dilate the strictures. Intraoperatively, each patient received an intraductal wash with $100 \mathrm{mg}$ 
Table 2 Selected methods to treat sialadenitis from irradiation

\begin{tabular}{|c|c|c|c|}
\hline Treatment strategies & Studies & Study characteristics & Conclusions \\
\hline \multicolumn{4}{|l|}{ Radioiodine irradiation } \\
\hline $\begin{array}{l}\text { Enhance flow of saliva by gland } \\
\text { massage and by avoiding } \\
\text { dehydration; use of sialogogues to } \\
\text { stimulate salivary secretion; } \\
\text { antibacterial/anti-inflammatory } \\
\text { medication as needed }\end{array}$ & $\begin{array}{l}\text { Multiple reports } \\
\text { include this } \\
\text { regimen as } \\
\text { standard [52, } \\
78]\end{array}$ & $\begin{array}{l}\text { No critical randomized controlled } \\
\text { studies identified for analysis }\end{array}$ & $\begin{array}{l}\text { These recommendations are frequently } \\
\text { presented as adequate treatment for } \\
\text { most cases of radioiodine sialadenitis } \\
\text { with other intervention regarded as } \\
\text { supplementary to this standard therapy } \\
\text { as per trials listed below }\end{array}$ \\
\hline $\begin{array}{l}\text { Pilocarpine administered orally as } \\
\text { parasympathetic agent (non- } \\
\text { selective muscarinic agent with } \\
\text { mild B-adrenergic activity) }\end{array}$ & $\begin{array}{l}\text { Aframian et al. } \\
{\left[74^{\bullet}\right]}\end{array}$ & $\begin{array}{l}\text { Human (clinical) study-four of five } \\
\text { patients with xerostomia after } \mathrm{I}^{131} \\
(150-550 \mathrm{mCi} \text { ) were shown to have } \\
\text { improved stimulated and unstimulated } \\
\text { salivary flow after ingestion of } 5 \mathrm{mg} \\
\text { pilocarpine }\end{array}$ & $\begin{array}{l}\text { Short-term pilocarpine increased } \\
\text { salivary output to "open a new } \\
\text { avenue" for treatment of radioiodine- } \\
\text { induced xerostomia with large-scale } \\
\text { long-term study needed }\end{array}$ \\
\hline \multicolumn{4}{|l|}{ Sialendoscopy treatment } \\
\hline $\begin{array}{l}\text { Sialendoscopy enabling dilation of } \\
\mathrm{I}^{131} \text {-induced ductal stenosis and } \\
\text { clearance of mucus plugs and } \\
\text { "ductal wash" with } 100 \mathrm{mg} \\
\text { hydrocortisone }\end{array}$ & $\begin{array}{l}\text { Nahlieli and } \\
\text { Nazarian [51•] }\end{array}$ & $\begin{array}{l}\text { Human (clinical) study-first } \\
\text { description of use of sialendoscopy to } \\
\text { treat } 15 \text { patients with hydrostatic } \\
\text { pressure by "continuous lavage" } \\
\text { punctuated by "saline torrent" dilation } \\
\text { for each patient with one additional } \\
\text { patient treated with a sialoballoon }\end{array}$ & $\begin{array}{l}\text { Successful mechanical dilation of the } \\
\text { strictures not always achieved but with } \\
\text { "excellent toileting"... "symptomatic } \\
\text { improvement is always achieved" }\end{array}$ \\
\hline $\begin{array}{l}\text { Sialendoscopy as method to direct } \\
\text { balloon or endoscopic sheath } \\
\text { dilation of narrowing identified by } \\
\text { sialography (no steroid insufflation) }\end{array}$ & Kim et al. [78] & $\begin{array}{l}\text { Human (clinical) study-six patients } \\
\text { with post- } \mathrm{I}^{131} \text { strictures treated by } \\
\text { balloon dilation and endoscopic sheath } \\
\text { dilation }\end{array}$ & $\begin{array}{l}\text { Three failures out of six patients } \\
\text { because of total duct obstruction for } \\
\text { two patients and one patient with } \\
\text { severe stenosis preventing passage of } \\
\text { balloon, leading to recommendation } \\
\text { that interventional sialendoscopy be } \\
\text { performed before development of } \\
\text { severe symptoms occurs }\end{array}$ \\
\hline $\begin{array}{l}\text { Sialendoscopy to irrigate debris } \\
\text { and instill medication ( } 40 \mathrm{mg} \\
\text { triamcinolone diluted in saline) }\end{array}$ & $\begin{array}{l}\text { Bomeli et al. } \\
\text { [78] }\end{array}$ & $\begin{array}{l}\text { Human (clinical) study-12 patient } \\
\text { addressed with success by cannulation } \\
\text { of } 27 \text { of } 32 \text { targeted glands }\end{array}$ & $\begin{array}{l}\text { Symptom improvement for } 9 \text { of } 12 \\
\text { patients treated-two of the failures } \\
\text { ascribed to inability to cannulate past } \\
\text { stenosis or masseteric bend in duct of } \\
\text { parotid }\end{array}$ \\
\hline $\begin{array}{l}\text { Sialendoscopy with dilation of the } \\
\text { puncta to introduce the } \\
\text { sialendoscope with flushing of the } \\
\text { ductal system (no steroid } \\
\text { insufflation) }\end{array}$ & $\begin{array}{l}\text { Prendes et al. } \\
\text { [52] }\end{array}$ & $\begin{array}{l}\text { Human (clinical) study-11 patients } \\
\text { with } 23 \text { of } 24 \text { parotid ducts } \\
\text { successfully cannulated; all five } \\
\text { submandibular ducts cannulated }\end{array}$ & $\begin{array}{l}\text { Complete resolution of symptoms for } 6 \\
(54 \%) \text {, partial improvement for } 4 \\
\text { (36\%), and no improvement for one } \\
\text { patient who was subsequently treated } \\
\text { by parotidectomy }\end{array}$ \\
\hline \multicolumn{4}{|l|}{ External beam irradiation } \\
\hline $\begin{array}{l}\text { Hypnosis as a method for } \\
\text { "optimizing } \\
\text { the physiologic environment for } \\
\text { salivation by cortical stimulation" } \\
\text { and "counteracting negative } \\
\text { expectancy" }\end{array}$ & Schiff et al. [84] & $\begin{array}{l}\text { Human (clinical) study-prospective } \\
\text { study of } 12 \text { patients (without a control } \\
\text { group) with refractory xerostomia } \\
\text { after external beam irradiation } \\
\text { evaluated with questionnaire and } \\
\text { sialometry }\end{array}$ & $\begin{array}{l}\text { Improvement in symptoms correlated } \\
\text { with extent of exposure to hypnosis } \\
\text { but did not correlate with stimulated } \\
\text { and unstimulated salivary flow, which } \\
\text { did not improve with hypnosis }\end{array}$ \\
\hline $\begin{array}{l}\text { Gene therapy to induce functional } \\
\text { water channels in ductal cells to } \\
\text { establish an osmotic gradient } \\
\text { directing fluid intraluminally }\end{array}$ & Baum et al. [35] & $\begin{array}{l}\text { Human (clinical) study_phases I/II } \\
\text { retrograde instillation of adenovirus } \\
\text { vector delivering cDNA for the water } \\
\text { channel aquaporin-1 (AGP1) for } \\
\text { patients with xerostomia after external } \\
\text { beam irradiation }\end{array}$ & $\begin{array}{l}\text { Enhanced parotid flow rate for } 6 \text { of } 11 \\
\text { treated subjects }\end{array}$ \\
\hline
\end{tabular}

hydrocortisone followed by a postoperative week of oral antibiotics. They reported the value of "toileting" the glands by use of this approach and, although they were unable to successfully dilate all of the strictures (especially the severe ones), they reported that "symptomatic improvement is always achieved". 
A more recent (2012) meta-analysis by Strychowsky et al. [76] of the global use of sialendoscopy for all causes of salivary obstruction reported sialendoscopy to be "efficacious, safe, and gland-preserving for the treatment of obstructive major salivary gland disease". Although their review focused on other disorders not associated with radiation (for example salivary stones) they did include radioiodine sialadenitis. They described sialendoscopy for treatment of radioiodine-induced sialadenitis as "relatively novel", with success ranging from 50 to $100 \%$. The electronic literature search by these investigators targeted publications up to October 2010 and included the initial 15 patients in Nahlieli's study. They identified two other studies for a total of 33 patients treated with sialendoscopy for radioiodine-induced sialadenitis. Twelve of these patients were reported by Bomeli et al. [77] as having sialendoscopy for treatment of 20 parotid and 12 submandibular glands.

Bomeli et al. [77] reported successful sialendoscopy for 27 of the 32 glands addressed (84 \%). These investigators defined technical success as the ability to cannulate the ductal system, remove debris by irrigation, and instill medication $(40 \mathrm{mg}$ triamcinolone acetonide suspension (Kenalog 40) diluted in $5 \mathrm{~cm}^{3}$ sterile saline) through the irrigating channel of the scope. Reasons cited for failure in accomplishing these objectives included an acute masseteric bend of the parotid duct (one patient), severe ductal stenosis (three patients), and inability to remove a parotid stone because of ductal stenosis (one patient). Nine of the 12 treated patients reported symptomatic improvement. Two of the failures were attributed to unsuccessful sialendoscopy. The single patient with successful sialendoscopy but without symptomatic improvement had recurrence of symptoms one month after the initial sialendoscopy that failed to improve despite four additional sialendoscopies.

The final six patients included in the review by Strychowsky were those of Kim et al. [78], who selected patients for sialendoscopy on the basis of failure to respond to conservative management of the post- $\mathrm{I}^{131}$ symptoms of salivary swelling and pain or dry mouth. Conservative management consisted of "aggressive salivary massage, hydration, and medication such as steroids, antibiotics, sialogogues, and nonsteroidal anti-inflammatory drugs". Their criteria for performing sialendoscopy also included demonstration of stenosis of a duct on sialography. Successful treatment of three patients included duct dilation with a balloon or "endoscopic sheath". Three failures included two cases of total obstruction (unable to pass the sialendoscope) and one failure to move the sialoballoon past the stenotic area. The three cases treated successfully had no recurrence of symptoms during 8-10 months follow-up. Kim et al. concluded that interventional sialendoscopy should be performed before development of severe symptoms associated with the severe duct stenosis that may preclude successful dilation.

The most recent series analyzing therapeutic sialendoscopy for management of radioiodine sialadenitis is that of Prendes et al. [52], who treated 11 patients with a total of 23 parotid glands and five submandibular glands. Conservative management, listed as including salivary gland massage, warm compresses, aggressive hydration, sialogogues, oral steroids, and cholinergic agonist medications had failed for all patients. Six of the 11 patients had received $\mathrm{I}^{131}$ on more than one occasion and one patient had been treated for Grave's disease. These investigators identified "typical" sialendoscopic findings including pale ductal mucosa, thick mucus plugs, ductal debris, and stenosis of the lumen. Treatment consisted of dilation of the ductal puncta to introduce the sialendoscope with copious saline irrigation of the ductal system. Ductal instillation of steroids was not included in this treatment. Some improvement of symptoms was observed for $91 \%$ of patients, with $55 \%$ rendered symptom free. The investigators attributed these favorable results to dilation of the papilla and ducts coupled with saline hydraulic dilation of the ductal lumen and flushing of debris and thick mucus plugs from the duct. They concluded that sialendoscopy for radioiodine-induced sialadenitis is a viable and safe therapeutic option for patients with symptoms refractory to conservative therapy. These investigators also acknowledged heterogeneity in reported surgical approaches and that their technique differed from previous reports in that neither steroid insufflation nor balloon dilation was used in their series.

\section{Steroid Infusion}

Emerging evidence suggests the value of steroid infusion through duct cannulation for some patients to address the pain and swelling associated with salivary inflammation [79]. This approach has been successful in helping patients with Sjögren's syndrome [80]. An isolated report of similar value for treatment of patients with long-term $\mathrm{I}^{131}$ sialadenitis suggests the possibility of application of this treatment [45].

\section{Gene Therapy}

A focused effort by Baum et al. [81] on gene therapy for salivary disorders addressed the concepts that high-dose irradiation may destroy the function of acinar cells and that the epithelial ductal cells are incapable of fluid secretion. The strategy used by this laboratory to restore saliva exploited the potential of surviving duct cells to generate an osmotic gradient directing fluid flow into the gland 
lumen. They reported the possibility of instilling the gene for the water channel aquaporin-1 (AQP1) into the ductal epithelium by use of adenoviral vectors. Administration of the AQP1 gene was successful in animal models and led to human trials by the same laboratory [82].

The first human clinical trial (phases I/II) was recently concluded and used this strategy to induce functional water channels in salivary duct cells. Baum et al. [35] reported that instillation of an adenovirus (Ad5) vector into a single parotid gland was safe, that hAQP1 gene transfer enhanced parotid flow rate in 6 of 11 treated subjects, and that the peak elevation of salivary flow after administration was variable-occurring much later than expected from previous animal studies (occurring at days 7, 14, 28, and 42). Pretreatment sialograms were obtained in this study, both to establish evidence for radiation damage and to assess for appropriate volume to instill. Their technique included IV glycopyrrolate $(4 \mu \mathrm{g} / \mathrm{kg})$ intravenously $30 \mathrm{~min}$ before cannulating the duct with a 22 gauge catheter used to infuse AdhAQP1, with the cannula held in place for $10 \mathrm{~min}$. These investigators concluded that their results are "cautiously encouraging" - with further work to study hAQP1 gene transfer to include vectors other than the Ad5.

\section{Hypnosis}

Hypnosis for management of post-irradiation (external beam therapy $\geq 5,000 \mathrm{rad}$ ) xerostomia has been addressed in a prospective study of 12 patients who were refractory to therapy with pilocarpine [83]. This observational uncontrolled study identified subjective improvement (via a questionnaire) in 8 of the 12 patients after hypnotherapy. No objective measurement of salivary flow was performed to corroborate this finding.

\section{Other Efforts}

Initial trials of electrical stimulation of the tongue and palate, and hyperbaric oxygen therapy have not proved these to be of benefit for treatment of post-irradiation sialadenitis $[84,85]$. Most patients frequently ingest water to treat the dry mouth. A large number of artificial saliva preparations are available (Hoffman HT (ed) Iowa Head and Neck Protocols "Management of Xerostomia" https:// wiki.uiowa.edu/display/protocols/Management + of + Xerostomiaxerostomia accessed 29 December 2013).

A recent Cochrane meta-analysis (2011) addressed topical therapy for management of dry mouth by evaluation of 36 randomized trials involving 1,597 participants [86]. These investigators concluded there was "no strong evidence from this review that any topical therapy is effective for relieving the symptom of dry mouth". They elaborated further that acidic products and preparations containing sugar should be avoided by patients with xerostomia. They also reported that oxygenated glycerol trimester saliva substitute was more effective at relieving xerostomia symptoms than water-based electrolyte spray, and that a gel-releasing device worn in the mouth may be effectivebut more research was required for conclusive proof of this.

Recently completed and actively recruiting clinical trials studying approaches to the management of xerostomia can be accessed on-line by searching for "xerostomia" within the site titled "ClinicalTrials.gov" http://clinicaltrials.gov/ accessed 24 December 2013.

\section{Conclusion}

The reported prevalence of radioiodine sialadenitis in controlled studies probably underestimates the full effect of $\mathrm{I}^{131}$ treatment. Excluded from these controlled studies are patients with other causes of xerostomia (e.g. medication) and salivary swelling (e.g. autoimmune salivary disorders). In addition, the salivary hypofunction expected to develop with menopause, aging, and use of medications with drying properties, for example diuretics and anti-depressants, would be expected to further expand the longer-term negative effect of $\mathrm{I}^{131}$ therapy.

Novel approaches to preventing radiation damage to the salivary glands include gland infusion or injection of protective proteins (tousled proteins), genetic material in viral vector therapy (hKGF), and neuro-effector blockade (botulinum toxin). Innovative approaches to restoring salivary function to damaged glands include gene therapy (cDNA for AQP1), use of parasympathetic stimulation (pilocarpine), and hypnosis.

Established approaches to addressing $\mathrm{I}^{131}$ sialadenitis include avoidance of radioiodine treatment and, when treatment is necessary, limiting the dose of radioiodine. Vigorous hydration before, during, and after treatment is a widely accepted but not rigorously tested management approach. Gland massage supplemented with anti-staphylococcal antibiotics and anti-inflammatory medications is widely accepted intervention that also have not been assessed in randomized in clinical trials. Questions persist regarding the value sialogogues (lemon-drops) and sialorrheics (pilocarpine) at the time of treatment.

The five publications (including one review article) that have addressed the use of sialendoscopy for management of radioiodine sialadenitis all support its value. Each of these studies identified sialendoscopy as useful for dilating strictures and removing debris by irrigation. Three of these studies used sialendoscopy to concurrently assist intraductal delivery of steroids. Expanded use of sialendoscopy through early intervention has been confirmed to address radioiodine-induced ductal strictures when symptoms are 
mild to moderate, and before the strictures are severe enough to limit the capacity for successful dilation.

Acknowledgments The authors wish to convey their respect and admiration for Michael Finkelstein DDS, MS (1951-2013), Professor, Department of Oral Pathology, Radiology and Medicine, University of Iowa.

\section{Compliance with Ethics Guidelines}

Conflict of Interest Henry T. Hoffman, Umar S. Chaudhry, Yusuf Menda, and Robert A. Robinson declare no conflicts of interest.

Human and Animal Rights and Informed Consent This article does not contain any studies with human or animal subjects performed by the authors.

\section{References}

Recently published papers of particular interest have been highlighted as:

- Of importance

- Of major importance

1. - Silberstein EB. Radioiodine: the classic theranostic agent. Semin Nucl Med. 2012;42:164-70. This review of the medical use of radioiodine offers an excellent historical perspective.

2. Fermi E. Radioactivity induced by neutron bombardment. Nature. 1934;122:201.

3. Sawin CT, Becker DV. Radioiodine and the treatment of hyperthyroidism. The early history. Thyroid. 1997;7:163-76.

4. Becker DV, Sawin CT. Radioiodine and thyroid disease: the beginning. Semin Nucl Med. 1996;26(3):155-64.

5. - Hieu TT, Russel AW, Cuneo R, Clark J, Kron T, Hall P, Doi SA. Cancer risk after medical exposure to radioactive iodine in benign thyroid diseases: a meta-analysis. Endocr Relat Cancer. 2012;19(5):645-55. This comprehensive analysis of publications (meta-analysis) offers insight into the oncogenic risk in administering radioiodine.

6. Jonklaas J, Cooper DS, Ain KB, Bigos T, Brierley JD, et al. Radioiodine therapy in patients with stage I differentiated thyroid cancer. Thyroid. 2010;20(12):1423-4.

7. Schlumberger M, Catargi B, Borget I, Deandreis D, Zerdoud S, Bridji B, Bardet S, Leenhardt L, Bastie D, Schvartz C, Vera P, Morel O, Benisvy D, Bournaud C, Bonichon F, Dejax C, Toubert ME, Leboulleux S, Ricard M, Benhamou E, Tumeurs de la Thyroïde Refractaires Network for the Essai Stimulation Ablation Equivalence Trial. Strategies of radioiodine ablation in patients with lowrisk thyroid cancer. N Engl J Med. 2012;366(18):1663-73. doi:10. 1056/NEJMoa1108586.

8. Bonnet S, Hartl D, Leboulleux S, et al. Prophylactic lymph node dissection for papillary thyroid cancer less than $2 \mathrm{~cm}$ : implication for radioiodine treatment. J Clin Endocrinol Metab. 2009;94:1162-7.

9. Sawka AM, Brierley JD, Tsang RW, Thabane L, Rotstein L, Gafni A, Straus S, Goldstein DP. An updated systematic review and commentary examining the effectiveness of radioactive iodine remnant ablation in well-differentiated thyroid cancer. Endocrinol Metab Clin N Am. 2008;37:457-80.

10. Haymart MR, Muenz DG, Stewart AK, Griggs JJ, Banerjee M. Disease severity and radioactive iodine use for thyroid cancer. J Clin Endocrinol Metab. 2013;98(2):678-86.
11. Jarzab B, Handkiewicz-Junak D, Wloch J. Juvenile differentiated thyroid carcinoma and the role of radioiodine in its treatment: a qualitative review. Endocr Relat Cancer. 2005;12:773-803.

12. Cooper DS, Doherty GM, Haugen BR, et al. Revised American Thyroid Association management guidelines for patients with thyroid nodules and differentiated thyroid cancer. Thyroid. 2009;19(11):1167-214.

13. Carballo M, Quiros RM. To treat or not to treat: the role of adjuvant radioiodine therapy in thyroid cancer patients. J Oncol. 2012, Article ID 707156. doi:10.1155/2012/707156.

14. Rubino C, de Vathaire F, Dottorini ME, Hall P, Schvartz C, Couette JED, Dondon MG, Abbas MT, Langlois C, Schlumberger $\mathrm{M}$. Second primary malignancies in thyroid cancer patients. Br J Cancer. 2003;89:1638-44.

15. - Mandel SJ, Mandel L. Radioactive iodine and the salivary glands. Thyroid. 2003;13(3), 265-71. The shortcomings of this otherwise excellent review article favorably reflect progress made over the past decade-many of the points made in this article were correct at the time but are not now.

16. Almeida JP, Sanabria AE, Pereira EN, Kowalski LP. Late side effects of radioactive iodine on salivary gland function in patients with thyroid cancer. Head Neck. 2011;33:686-90.

17. Maier $\mathrm{H}, \mathrm{Bihl} \mathrm{H}$. Effect of radioactive iodine therapy on parotid gland function. Acta Otolaryngol. 1987;103(3-4):318-24.

18. Slovis TL. Chapter 699: biologic effects of radiation on children, Part XXXIII — environmental health hazards in Kleigman: Nelson textbook of pediatrics. In: Biologic effects of radiation on children. Philadelphia: Elsevier Saunders; 19th ed. 2011.

19. Ann Y-S, Yoon J-K, Lee SJ, Song H-S, Yoon S-H, Jo K-S. Symptomatic late-onset sialadenitis after radioiodine therapy in thyroid cancer. Ann Nucl Med. 2013;27:386-91.

20. •• Jeong SY, Kim HW, Lee S-W, Ahn B-C, Lee J. Salivary gland function 5 years after radioactive iodine ablation in patients with differentiated thyroid cancer: direct comparison of pre- and postablation scintigraphies and their relation to xerostomia symptoms. Thyroid. 2013;23(5):609-16. A remarkable study identifying subjective complaints of xerostomia (17.9\%) as underrepresent the more pervasive changes seen through objective analysis of salivary function (scintigraphy) (47.4\%) among 213 patients followed at least 5 years following treatment.

21. - Silberstein EG. Reducing the incidence of $I^{131}$-induced sialadenitis: the role of pilocarpine. J Nucl Med. 2008;49(4):546-9. No benefit seen in pilocarpine group compared to control - reason for lack of benefit ascribed to success of "Cincinnati regimen" used for both the study and control groups with equally good results (no acute sialadenitis).

22. Chow SM. Side effects of high-dose radioactive iodine for ablation or treatment of differentiated thyroid carcinoma. J Hong Kong Coll Radiol. 2005;8:127-35.

23. Van Nostrand D, Neutze J, Atkins F. Side effects of 'rational dose' iodine-131 therapy for metastatic well-differentiated thyroid carcinoma. J Nucl Med. 1986;27:1519-27.

24. Alexander C, Bader JB, Schaefer A, Finke C, Kirsch CM. Intermediate and long-term side effects of high-dose radioiodine therapy for thyroid carcinoma. J Nucl Med. 1998;39:1551-4.

25. Walter MA, Turtshchi CP, Schindler C, et al. The dental safety profile of high-dose radioiodine therapy for thyroid cancer: long term results of a longitudinal cohort study. J Nucl Med. 2007;48:1620-5.

26. Kita T, Yokoyama K, Higuchi T, et al. Multifactorial analysis of the short-term side effects occurring within 96 hours after radioiodine-131 therapy for differentiated thyroid carcinoma. Ann Nucl Med. 2004;18:345-9.

27. Sawka AM, et al. American Cancer Society 2008 cancer facts and figures. http://ww.cancer.org/docroot/stt/stt_0.asp?from=fast (2009). Accessed 5 Nov 2008. 
28. Sawka AM, Thabane L, Parlea L, Ibrahim-Zada I, Tsang RW, Brierley JD, Straus S, Ezzat S, Goldstein DP. Second primary malignancy risk after radioactive iodine treatment for thyroid cancer: a systematic review and meta-analysis. Thyroid. 2009;19(5):451-7.

29. Wolff M, Kleinberg I. The effect of ammonium glycopyrrolate (Robinul)-induced xerostomia on oral mucosal wetness and flow of gingival crevicular fluid in humans. Arch Oral Biol. 1999;44:97-102.

30. Dawes C. How much saliva is enough for avoidance of xerostomia. Caries Res. 2004;38:236-40.

31. Dawes C. Physiological factors affecting salivary flow rate, oral sugar clearance, and the sensation of dry mouth in man. J Dent Res. 1987;66:648-53.

32. Ghezzi EM, Lange LA, Ship JA. Determination of variation of stimulated salivary flow rates. J Dent Res. 2000;79:1874-8.

33. Schneyer LH. Source of resting total mixed saliva of man. J Appl Physiol. 1956;9(1):79-81.

34. Banal M, Mohanti BK, Shah N, et al. Radiation related morbidities and their impact on quality of life in head and neck cancer patients receiving radical radiotherapy. Qual Life Res. 2004; 13:481-8.

35. Baum BJ, Alevizos I, Zheng C, Cotrim AP, Liu S, MCCullagh L, et al. Early responses to adenoviral-mediated transfer of the aquaporin-1 cDNA for radiation-induced salivary hypofunction. Proc Natl Acad Sci USA. 2012;109(47):19403-7.

36. Vissink A, et al. Clinical management of salivary gland hypofunction and xerostomia in head-and-neck cancer patients: successes and barriers. Int $\mathrm{J}$ Radiat Oncol Biol Phys. 2010;78(4):983-91.

37. Jensen SB, et al.; Salivary Gland Hypofunction/Xerostomia Section, Oral Care Study Group, Multinational Association of Supportive Care in Cancer (MASCC)/International Society of Oral Oncology (ISOO). A systematic review of salivary gland hypofunction and xerostomia induced by cancer therapies: prevalence, severity and impact on quality of life. Support Care Cancer. 2010;18(8):1039-60.

38. Almeida JP, Vartanian JG, Kowalski LP. Clinical predictors of quality of life in patients with initial differentiated thyroid cancers. Arch Otolaryngol Head Neck Surg. 2009;135(4):342-6.

39. Dagan T, Bedrin L, Horowitz Z, et al. Quality of life of welldifferentiated thyroid carcinoma patients. J Laryngol Otol. 2004;118(7):537-42.

40. Capps EF, Kinsella JJ, Gupta M, Bhatki AM, Opatowsky MJ. Emergency imaging assessment of acute, nontraumatic conditions of the head and neck. Radiographics. 2010;30(5): 1335-52.

41. Mehanna H, McQueen A, Robinson M, Paleri V. Salivary gland swellings. Clin Otolaryngol. 2013;38(1):58-65.

42. Burke CJ, Thomas RH, Howlett D. Imaging the major salivary glands. Br J Oral Maxillofac Surg. 2011;49(4):261-9 (Epub 9 April 2010).

43. Bialek EJ, Jakubowski W, Zajkowski P, Szopinski KT, Osmolski A. US of the major salivary glands: anatomy and spatial relationships, pathologic conditions, and pitfalls. Radiographics. 2006;26(3):745-63.

44. Abdullah A, Rivas FF, Srinivasan A. Imaging of the salivary glands. Semin Roentgenol. 2013;48(1):65-74.

45. Choi N, Schularick M, Diggelmann H, Smoker W, Hoffman H. Radiology quiz case 1. Iodine 131-induced sialadenitis. Arch Otolaryngol Head Neck Surg. 2012;138:597-8.

46. Nabaa B, Takahashi K, Sasaki T, Okizaki A, Aburano T. Assessment of salivary gland dysfunction after radioiodine therapy for thyroid carcinoma using non-contrast-enhanced CT: the significance of changes in volume and attenuation of the glands. Am J Neuroradiol. 2012;33(10):1964-70 (Epub 3 May 2012).
47. Sun Z, Zhang Z, Fu K, Zhao Y, Liu D, Ma X. Diagnostic accuracy of parotid CT for identifying Sjögren's syndrome. Eur J Radiol. 2012;81(10):2702-9 (Epub 28 Jan 2012).

48. Cavalieri RR. Iodine metabolism and thyroid physiology: current concepts. Thyroid. 1997;7:177-81.

49. Solans R, Bosch JA, Galofre P, Porta F, Rosello J, et al. Salivary and lacrimal gland dysfunction (sicca syndrome) after radioiodine therapy. J Nucl Med. 2011;42:738-43.

50. Jentzen W, Schneider E, Freudenberg L, Eising EG, Gorges R, Muller SP, Brandau W, Bockisch A. Relationship between cumulative radiation dose and salivary gland uptake associated with radioiodine therapy of thyroid cancer. Nucl Med Commun. 2006;27(8):669-79 (from references 20-22 in this article).

51. - Nahlieli O, Nazarian Y. Sialadenitis following radioiodine therapy - a new diagnostic and treatment modality. Oral Dis. 2006;12:476-9. 1st Description of use of sialendoscopy to treat 15 patients with hydrostatic pressure through 'continuous lavage' punctuated by 'saline torrent' dilation in each patient with one additional patient treated with a sialoballoon.

52. Prendes BL, Orloff LA, Eisele DW. Therapeutic Siaolendoscopy for the management of Radioiodine sialadenitis. Arch Otolaryngol Head Neck Surg. 2012;138(1):15-9.

53. Maier $\mathrm{H}, \mathrm{Bihl} \mathrm{H}$. Effect of radioactive iodine therapy on parotid gland function. Acta Otolaryngol. 1987;103:318-24.

54. Abok K, Burnk U, Jung B, et al. Morphologic and histochemical studies on the differing radiosensitivity of ductular and acinar cells of the rat submandibular gland. Virchows Arch B. 1984;45:443-60.

55. Nagler RM. Effects of head and neck radiotherapy on major salivary glands-animal studies and human implications. In Vivo. 2003;17:369-75.

56. Konings AW, Coppes RP, Vissink A. On the mechanism of salivary gland radiosensitivity. Int $\mathrm{J}$ Radiat Oncol Biol Phys. 2005;62(4):1187-94.

57. Coppes RP, Zeilstr LJW, Kampinga HH, et al. Early to late sparing of radiation damage to the parotid gland by adrenergic and muscarinic receptor agonists. Br J Cancer. 2001;2038:1055-63.

58. Mallick U, Harmer C, Yap B, Wadsley J, Clarke S, Moss L, Nicol A, Clark PM, Farnell K, McCready R, Smellie J, Franklyn JA, John R, Nutting CM, Newbold K, Lemon C, Gerrard G, AbdelHamid A, Hardman J, Macias E, Roques T, Whitaker S, Vijayan R, Alvarez P, Beare S, Forsyth S, Kadalayil L, Hackshaw A. Ablation with low-dose radioiodine and thyrotropin alfa in thyroid cancer. N Engl J Med. 2012;366(18):1674-85. doi:10.1056/ NEJMoa1109589.

59. Orlov S, Freeman JL, Walfish PG. Radioiodine ablation in lowrisk thyroid cancer. N Engl J Med. 2012;367(7):672. doi:10.1056/ NEJMc1206712\#SA1.

60. Nixon IJ, Ganly I, Patel SG, Palmer FL, DiLorenzo MM, Greqal RK, Larson SM, Tuttle RM, Shaha A, Shah JP. The results of selective use of radioactive iodine on survival and on recurrence in the management of papillary thyroid cancer, based on Memorial Sloan-Kettering Cancer Center risk group stratification. Thyroid. 2013;23(6):683-94.

61. Haugen BR. Radioiodine remnant ablation: current indications and dosing regimens. Endocr Pract. 2012;18(4):604-10.

62. • Nakada K, Ishibashi T, Takei T, Hirata K, Shinohara K, Karoh S, Zhao S, Tamaki N, Noguchi Y, Noguchi S. Does lemon candy decrease salivary gland damage after radioiodine therapy for thyroid cancer. J Nucl Med. 2005;46:261-6. Xerostomia, altered taste and sialadenitis highest in the treated with candy at the time of treatment.

63. Van Nostrand D, Atkins F, Bandaru VV, Chennupati SP, Moreau S, Burman K, Wartofsky L. Salivary gland protection with sialogogues: a case study. Thyroid. 2009;19(9):1005-8.

64. Van Nostrand D, Bandaru V, Chennupati S, Wexler J, Kulkarni K, Atkins F, Mete M, Gadwale G. Radiopharmacokinetics of 
radioiodine in the parotid glands after the administration of lemon juice. Thyroid. 2010;20(10):1113-9.

65. Patt HM, Tyree EB, Straube RL, et al. Cysteine protection against X irradiation. Science. 1949;110:213-4.

66. Bohuslavizki KH, Klutmann S, Jenicke L, Brenner W, Feyerabend B, Henze E, et al. Radioprotection of salivary glands by S-2(3-aminopropylamino)-ethylphosphorothioic acid (amifostine) in high-dose radioiodine treatment: results obtained in a rabbit animal model. Int J Radiat Oncol Biol Phys. 1999;45(1):181-6.

67. Bohuslavizki KH, Klutmann S, Jenicke L, Kroger S, Buchert R, Mester J, Clausen M. Salivary gland protection by S-2-(3-aminopropylamino)-ethylphosphorothioic acid (amifostine) in highdose radioiodine treatment: results obtained in a rabbit animal model and in a double-blind multi-arm trial. Cancer Biother Radiopharm. 1999;14(5):337-47.

68. - Ma C, Xie J, Jiang Z, Wang G, Zuo S. Does amifostine have radioprotective effects on salivary glands in high-dose radioactive iodine-treated differentiated thyroid cancer. Eur J Nucl Med Mol Imaging. 2010;37:1778-85. Reviewed of randomized controlled studies concluded there was no radioprotective effect of amifostine on the salivary glands.

69. Bohuslavizki KH, Klutmann S, Brenner W, Mester J, Henze E, Clausen M. Salivary gland protection in high-dose radioiodine treatment: results of a double blind placebo-controlled study. J Clin Oncol. 1998;16:3542-9.

70. Kim SJ, Choi HY, Kim IJ, Kim YK, Jun S, Nam HY, et al. Limited cytoprotective effects of amifostine in high-dose radioactive iodine 131-treated well-differentiated thyroid cancer patients: analysis of quantitative salivary scan. Thyroid. 2008;18:325-31.

71. Ansiaux R, Baudelet C, Cron GO, et al. Botulinum toxin potentiates cancer radiotherapy and chemotherapy. Clin Cancer Res. 2006; 12:1276-83.

72. Meng Z, Garcia MK, Hu C, Chiang J, Chambers M, Rosenthal DI, Peng H, Zhang Y, Zhao Q, Zhao G, Liu L, Spelman A, Palmer JL, Wei Q, Cohen L. Randomized controlled trial of acupuncture for prevention of radiation-induced xerostomia among patients with nasopharyngeal carcinoma. Cancer. 2012;118(13):3337-44. doi:10.1002/cncr.26550.

73. Zheng C, Cotrim AP, Rowzee A, Swaim W, Sowers A, Mitchell JB, Baum BJ. Prevention of radiation-induced salivary hypofunction following hKGF gene delivery to murine submandibular glands. Clin Cancer Res. 2011;17(9):2842-51.

74. - Aframian DJ, Helcer M, Livni D, Markitziu A. Pilocarpine for the treatment of salivary glands' impairment caused by radioiodine therapy for thyroid cancer. Oral Dis. 2006;12:297-300. Short-term pilocarpine increased salivary output to 'open a new avenue' for treatment of radioiodine-induced xerostomia with large scale long-term study needed.

75. Brimhall J, Jhaveri MA, Yepes JF. Efficacy of cevimeline vs. pilocarpine in the secretion of salivary: a pilot study. Spec Care Dent. 2013;33(3):123-7.
76. Strychowsky JE, Sommer DD, Gupta MK, Cohen N, Nahlieli O. Sialendoscopy for the management of obstructive salivary gland disease. Arch Otolaryngol Head Neck Surg. 2012;138(6):541-7.

77. Bomeli SR, Schatkin B, Carrau RL, Walvekar RR. Interventional sialendoscopy for treatment of radioiodine-induced sialadenitis. Laryngoscope. 2009;119(5):862-7.

78. Kim JW, Han GS, Lee Sh, Lee DY, Kim YM. Sialoendoscopic treatment for radioiodine induced sialadenitis. Laryngoscope. 2007;117(1):133-6. Three failures out of 6 patients due to total duct obstruction in two patients and one patient with severe stenosis preventing passage of balloon leading to recommendation that interventional sialendoscopy be performed before development of severe symptoms occur.

79. Izumi M, Eguchi K, Nakamura H, Takagi Y, Kawabe Y, Nakamura T. Corticosteroid irrigation of parotid gland for treatment of xerostomia in patients with Sjogren's syndrome. Ann Rheum Dis. 1998;57(8):464-9.

80. Diggelmann H, Hoffman H. Steroid infusion for Sjogrens pub pending. ENT J. 2011 (accepted).

81. Baum BJ, Adriaansen J, Cotrim AP, Goldsmith CM, Perez P, Qi S, Rowzee AM, Zheng C. Gene therapy of salivary diseases. Methods Mol Biol. 2010;666:3-20.

82. Baum BJ, Zheng C, Cotrim AP, et al. Aquaporin-1 gene transfer to correct radiation-induced salivary hypofunction. Handb Exp Pharmacol. 2009;190:403-18.

83. Schiff E, Mogilner JG, Sella E, Doweck I, Hershko O, Ebn-Ayre E, Yarom N. Hypnosis for postradiation xerostomia in head and neck cancer patients: a pilot study. J Pain Symptom Manag. 2009;37(6): 1086-92.

84. Weiss WW, Brenman HS, Katz P, Bennett JA. Use of an electronic stimulator for the treatment of dry mouth. J Oral Maxillofac Surg. 1986;44:845-50.

85. Fontanesi J, Golden EB, Cianci P. Hyperbaric oxygen therapy can reverse radiation-induced xerostomia. J Hyperb Med. 1991;6:215-21.

86. Furness S, Worthington HV, Bryan G, Birchenough S, McMillan $R$. Interventions for the management of dry mouth: topical therapies. Cochrane Database Syst Rev. 2011;12. No. CD008934. Copyright 2011, The Cochrane Collaboration. Wiley. doi:10. 1002/14651858.CD008934.pub2.

87. Teymoortash A, Müller F, Juricko J, Bieker M, Mandic R, Librizzi D, Höffken H, Pfestroff A, Werner JA. Botulinum toxin prevents radiotherapy-induced salivary gland damage. Oral Oncol. 2009;45(8):737-9. doi:10.1016/j.oraloncology.2008.11.014.

88. Sunavala-Dossabhoy G, Palaniyandi S, Richardson C, De Benedetti A, Schrott L, Caldito G. TAT-mediated delivery of tousled protein to salivary glands protects against radiation-induced hypofunction. J Radiat Oncol Biol Phys. 2012;84(1):257-65. 